\title{
Leading Strategic Alliances: A Case Study
}

James L. Hall, Santa Clara University

\begin{abstract}
"Ford Motor Co. is launching a strategic review of ailing operations that could lead to ...broader alliances with other companies, according to people familiar with the situation" (Wall Street Journal, August, 2, 2006: 1). What are the odds of such alliances succeeding?
\end{abstract}

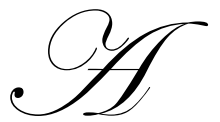

strategic alliance has been defined as "consisting of two or more organizations that contractually pool resources to achieve a long-term strategic purpose that is not possible for a single organization"(Judge, W. \& Ryman, J., 2001: 71). Research indicates that the number of alliances is growing rapidly, at an average rate of 25 percent per year (Parise, S. \& Casher, A., 2003). However, alliances do not have an effective track record. For example, Segil (1998) reports that 55 percent of alliances fail within three years. Other researchers (Ellis, C., 1996; Parise, S. \& Casher, A., 2003) also estimate the failure rate at 50 to 60 percent. This overall lack of success is probably due in large measure due to the frequent tensions between competition and co-operation inherent in alliances (Bharat and Tarun, 2004).

This case describes the experiences, tactics and strategies of General Dwight D. Eisenhower, the Supreme Allied Commander in WWII. The victory of the allied forces in Europe in WWII, 62 years ago, was, arguably, the culmination of the most significant, and successful, strategic alliance in history. However, prior to Ike's success as allied commander, the track record of waging war with coalitions was essentially one of failure. As Ike states, "even Napoleon's reputation as a brilliant military leader suffered when students in staff colleges came to realize he always fought against coalitions--and therefore against divided counsels and diverse political economic and military interests." Hence, Ike's success is particularly noteworthy. The lessons of that success are important today both because of the growth of strategic alliances in all business sectors, and because of the failure rate of strategic alliances.

Eisenhower (Ike) graduated from West Point in 1915 and, by 1918 had been promoted to Major and was senior to nearly all of his graduating class, despite seeing no active service in WWI. By October, 1918, he was promoted to Lt. Colonel and was running a state-side training camp with over 10,000 soldiers under his command. Ike remained at that rank in a shrinking, peacetime army until 1941. But his colleagues recognized his leadership ability. For example, Patton, six years his senior and with battlefield experience in WWI, predicted a future in which Ike would be Robert E. Lee and Patton would be Stonewall Jackson. One mentor, General Fox Connor, helped Ike get into the Command and General Staff College, a critical training program for potential general officers. Ike graduated first in his class. Subsequently, he served as an aide to General Douglas MacArthur when MacArthur was Army Chief of Staff, and then was asked by MacArthur to serve with him on special assignment in the Philippines. Between July, 1941 and September 1941, Ike played a key role in planning and organizing the Louisiana Maneuvers, the first US training maneuvers between entire armies, and subsequently was promoted to Brigadier General. In December, 1941, he was assigned to the War Department in Washington D.C., becoming Chief of Operations, and promoted to Major General, in March 1942. In June, 1942 he was assigned to London as Commanding General, U.S. Army in England, and promoted to Lt. General. .Subsequently he became allied commander, first of Operation Torch and then of Operation Overlord.

During Ike's assignments, four interesting characteristics manifested themselves. First, Ike proved to be a thorough student, and a quick study, of military strategy. For example, on December 14, 1941, during the Philippines crisis, General Marshall (Army Chief of Staff) gave Ike and a few other officers a 20 minute situation review and then asked, "What should be our line of action?" Ike responded, "Give me a few hours", and came back with an analysis that Marshall approved of and asked Ike to implement. Second, Ike was willing to stick his neck 
out and take actions that might have cost him his command. For example, contrary to official government policy, during Operation Torch (invasion of North Africa) Ike chose to work with a top admiral in the French navy, a collaborator with the Vichy government, as a necessary expedient to save allied and French lives. Third, during Operations Torch and Overlord (invasion of Europe), Ike was observed to exercise two styles of leadership. One was the role of a firm, confident, hard-driving general who was aggressive, outspoken and definite about what he wanted. The second was the "chairman of the board" style as Ike presided, rather than deciding, often getting his way by negotiation and compromise. With the latter style, Ike was sometimes observed to use a technique he learned from General MacArthur. Ike would initially criticize proposals he agreed with, and sound enthusiastic about ideas he didn't agree with. Ike believed that this approach reserved him his freedom of action while picking others' brains. Fourth, Ike's assignments included considerable variety. By his own account, he held a dozen different jobs since serving in the Philippines.

Early in Ike's career (1920s) he was told by one of his mentors, General Fox Connor (General Pershing's Chief of Staff in WWI), that the next war would be fought as part of a coalition of nations, thereby predisposing Ike to working in a strategic alliance. General Connor predicted that the allies would require "very well understood mechanisms and organisms to keep themselves together and not work at cross-purposes." Consequently, when Ike became allied commander in WWII, he stressed unity above national interests. He would immediately challenge any idea that appeared to him to only represent a nationalistic attitude or viewpoint. As a telling example, Ike relieved from duty a US Colonel who, in a dispute with a British officer, called him a British S.O.B. Ike told the Colonel that he was correct in the dispute, and that the British officer may have been an S.O.B., but that the Colonel committed a cardinal sin by calling him a British S.O.B. During Operation Torch (the invasion of North Africa), Ike came to realize that national interests and prejudice were more critical than the typical obstacles such as differences in equipment and staff procedures and methods of organization.

One of the important questions facing Ike was how to design the alliance structure. Over time, he decided on several important aspects. First, in contrast to the philosophy of "co-operation" that plagued leadership in WWI, Ike insisted on total operating command over all alliance forces. For example, based on his experiences with Operation Torch, Ike demanded control of air forces when he became allied commander of Operation Overlord, the invasion of Europe. Eventually he was given such control for a critical period of time--April 1944 to September 1944. Second, the structure included a Combined (US and British) Chiefs of Staff to which Ike reported, thereby buffering Ike somewhat from the (political) pressures of President Roosevelt and Prime Minister Churchill. (This decision was made primarily by Churchill and Roosevelt.) Third, Ike created a single chain of command, taking apart the US and British chains of command, with alternating US and British links. Fourth, Ike integrated two staff systems: the British use of coordinating committees and conferences to get things done vs. the US use of simple, small staffs under direct control, trying to keep the best of both. In fact, it seems that Ike chose (or was persuaded by the British to choose) the British model, but somehow gained more success with this model than its record would have predicted. Fifth, Ike faced the perennial structural decisions regarding centralization and decentralization. For example, during the Normandy campaign, which consisted of a relatively narrow front, Ike chose a centralized design, deciding on one battle commander (Montgomery) to be in charge of coordination between two army groups. After the Normandy breakthrough, and the early establishment of British and US army groups in France, British interests wanted Montgomery to continue in the role of commander of all ground troops. Instead, Ike chose a decentralized design, designating three commanders, with all three reporting to Ike.

An interesting dilemma facing Ike and his alliance partners is that of determining the extent to which there should be some kind of contractual provisions to protect partners' interests versus the need to maintain flexibility in uncertain environments and the impossibility of anticipating all possible contingencies. It seems clear that the alliances had few, if any, contractual provisions. The only point of agreement consistently agreed upon was that, at some point, Europe would be invaded; however, even the location and timing of that event were debated at length. Perhaps the level of trust between the members played a role.

Ike emphasized two aspects of the alliance. First, he made every effort to ensure that potential alliance partner resources were made available and used. These resources included British, Canadian and Australian troops and equipment, and also Great Britain as a staging base. Second, and perhaps less predictable, Ike worked hard at 
developing good relationships with the alliance partners. For example, soon after arriving in London Ike began the practice, despite powerful competing demands on his time, of meeting twice weekly with Churchill, both at Churchill's office and having dinner with Churchill at his residence. Although Ike's initial relationship with General DeGaulle might fairly be described as rocky, by the end of 1943 both men grew to admire and trust the other. This evolution was due, at least in part, by Ike's willingness both to stand up to DeGaulle and also Ike's willingness to admit when he was wrong. Also a part of this "relationship lever" was his ability to work with personalities, such as Churchill, DeGaulle, General Montgomery and General Patton, that often were brilliant but difficult, together with Ike's approach to delegation.

There was no manual or precedent that Eisenhower could consult on how to mold two (USA and British) nationalities that generally distrusted each other into a single, unified force. Several factors may have helped. First was Ike's ability to engage in fierce debate with prima donna personalities, while retaining respect, or even liking in some cases, for the other party. This ability was especially noteworthy given Ike's well known temper. Second was his willingness to put up with annoying, or inappropriate behavior, such as Patton's, in order to retain an individual's services for future battles. However, Ike could be very firm when conditions warranted it. For example, during a meeting between Ike and General Montgomery, Monty got a bit out of hand. Eisenhower leaned forward and touched Montgomery's knee. "'Steady Monty. You can't speak to me like that. I'm your boss." Third was Ike's approach to delegation which was influenced by his experiences, both positive and negative, with officers he served under. Ike insisted that subordinates act on their own conclusions in their own sphere of responsibility, and consequently tried not to micro manage. Also Ike believed in backing subordinates to the fullest and was quick to give credit to subordinates rather than claim the lion's share of the credit for favorable developments. Another characteristic of Ike's was his insistence, influenced by his association with General Marshall, that all staff and operations officers maintain a positive attitude, even in the face of dire challenges. Finally, Ike, perhaps counterintuitively given his insistence on being in command of all forces, believed that success, especially in allied commands is measured more by an ability to lead and persuade versus fixed notions of arbitrary command.

\section{CASE DISCUSSION QUESTIONS}

1. Why is it important to analyze strategic alliances?

2. What makes a strategic alliance potentially more difficult to lead than a single organization?

3. What aspects of Eisenhower's background and training contributed most significantly to his success as the leader of the WWII strategic alliance?

4. How would you describe Eisenhower's perspective on strategic alliances?
A. What was the basis of that perspective?
B. What did Eisenhower see as a major barrier to a strategic alliance's success?
C. How significant might such a barrier be to a current strategic alliance?

5. What steps did Eisenhower take to address the barrier(s) he identified?

A. How did he design the structure of the WWII alliance? What were the key elements of this design? How does that design match the conclusions of classical research on organizational design?

B. How important was Eisenhower's attention to the relationships between the members of the strategic alliance? What forms did these relationships take? What aspects of Eisenhower's behavior seemed to contribute significantly to his relationship-building?

6. Eisenhower was observed to use two distinct styles of leadership. What were they, and how do you think they each contributed to his success in leading the strategic alliance?

7. Eisenhower may not have enjoyed the amount of power over subordinates that often is attributed to the military command structure. What might be the implication(s) for leaders of strategic alliances in business? 


\section{GUIDELINES FOR INSTRUCTORS}

\section{Discussion Questions}

\section{Leading Strategic Alliances, A Case Study}

1. Although the number of strategic alliances is growing (at an average of approximately 25 percent per year, the failure rate is high, averaging over 50 percent within a three year period (see references cited in case).

2. The literature on organizational learning (see Bharat and Taren, 2004) suggests that alliances are difficult to mange due to frequent tensions between cooperation and competition. Such tensions are likely to exist in any alliance between two or more companies because they will be cooperating on some dimensions, but not all. For example, they might still be competing in certain markets or on certain product lines.

3. Several aspects of Ike's background and training warrant attention. Research suggests that the failure rate of strategic alliances may be partly due to the failure of companies to empower managers with the appropriate tools and skills (see Parise and Casher, 2003). Ike's background included a variety of training experiences, including planning (see the Louisiana maneuvers), and working with difficult personalities (such as General McArthur in the Philippines) over a 25 year period which doubtlessly prepared him well for some of the challenges of leading an alliance.

4. Ike's perspective on alliances probably derived mostly from the mentoring he received from veteran military leaders, such as Generals Fox and Marshall, of WWI. In particular, Ike became aware of the huge barrier that national self-interest could pose to a successful alliance. This is consistent with the research from the Darden School (see Ellis, 1996) which indicated that the answer to making alliances work is effective leaders who keep the alliance's best interests, versus members' self-interests, front and center.

5. Ike reinforced his perspective on alliances through decision-making and actions that affected both the structure of the alliance and the relationships between the members.

A. Ike shaped the design of the alliance's structure in several ways:

a. He requested total operating command (vs. the "spirit of cooperation" that prevailed in WWI).

b. He merged the chain(s) of command

c. He integrated the US and BR staff systems

d. $\quad \mathrm{H}$ made structural decisions based on the level of environmental stability (see Lawrence and Lorsch, 1965), choosing first a centralized structure during the Normandy campaign, and then a decentralized structure as the allied armies spread out across France.

B. Research on strategic alliances has tended to focus on either the value of the resources contributed by the members, or on the nature of the relationships between the parties (see Saxton, 1997). Saxton point out, however, that it seems likely that both areas are important, It is interesting to note, therefore, that Ike emphasized both areas. Examples of his relationship building included his social interactions with Prime Minister Churchill, and his efforts to develop a mutually-respected relationship with General DeGaulle.

6. Ike's two leadership styles were first, that of a firm, confident, hard-driving general, and second, that of "chairman of the board". Instructors will find this a good opportunity to discuss situational leadership (see Hersey, Blanchard and Johnson, 1996).

7. Students might believe that Ike had it easier, because of the military command structure, than leaders of strategic alliances in the business sector. However, the very real limits of Ike's power over his subordinates should make the parallels between Ike and business leaders of strategic alliances more apparent. Instructors might find it useful to introduce the interative method of decision-making described in Roberts (2005, Ch 8: 195-202). 